\title{
Active and Healthy Ageing at Work-A Qualitative Study with Employees 55 - 63 Years and Their Managers
}

\author{
Kerstin Nilsson ${ }^{1,2}$ \\ ${ }^{1}$ Division of Occupational and Environmental Medicine, Lund University, Lund, Sweden \\ ${ }^{2}$ Department of Work Science, Business Economics \& Environmental Psychology, Swedish University of Agricultural Sciences, \\ Alnarp, Sweden \\ Email: kerstin.nilsson@med.lu.se, swage.research@gmail.com
}

How to cite this paper: Nilsson, K. (2017) Active and Healthy Ageing at Work-A Qualitative Study with Employees 55 - 63 Years and Their Managers. Open Journal of Social Sciences, 5, 13-29. https://doi.org/10.4236/jss.2017.57002

Received: May 6, 2017

Accepted: June 30, 2017

Published: July 3, 2017

Copyright $\odot 2017$ by author and Scientific Research Publishing Inc. This work is licensed under the Creative Commons Attribution International License (CC BY 4.0).

http://creativecommons.org/licenses/by/4.0/

(c) (i) Open Access

\begin{abstract}
The proportion of elderly individuals in the population is increasing in most industrial countries. This demographic change increases the need of more people who work until an older age to maintain the welfare in the states. However, it is not clear if older employees are interested to in generally extend the working life to an older age. It is also not stated if managers in organizations are interested of extending their older employees working life. The overall aim of this study was to examine older employees own experience of their work situation and ageing at work. The aim was also to investigate their managers' attitude to them as older employees. The investigation was conducted by focusing group interviews with employees aged 55 - 63 years, and with their mangers aged 40 63 years. The findings stated that the older employees' consideration for an extend working life seemed to be based on their health and health problems in relation to their work situation; their personal economy; their managers attitude to them as elderly and the possibility to social inclusion at work; and their possibilities for self-crediting activities at work despite their age. The managers seem to have a positive attitude to some of the older employees' experience knowledge, if that was in the same direction as their own interest. Otherwise the mangers saw the older employees as problem and obsoleted. The managers were also negative to older employees who got health problems which effect the work production negatively. The older workers in this study described managers' importance to if they want to work in an extended working life. However, the managers seem not to understand their own importance in this and were not interested to keep all elderly in an extended working life.
\end{abstract}

\section{Keywords}

Older Worker, Employees, Managers, Age, Retirement, Work, Occupational 
Health, Public Health

\section{Introduction}

As a result of changing demographics in most industrial countries, the proportion of elderly individuals in the population is increasing [1] [2]. On average, people are living longer in retirement today than they did two generations ago; e.g. more than 33 per cent of men and 38 per cent of women in the EU-25 will be 60 years or older in 2050, compared with 18 per cent of men and 24 per cent of women in 2000 [3].

When the old age support ratio is increasing by need for social and medical care, a larger proportion of working hours is needed to maintain the welfare state [4]. Sweden is among the countries with the highest estimated old age dependency ratio for 2025 and unless changes are made, the level of compensation in the Swedish pension system will fall by $10-15$ per cent in coming years. Several countries have already raised the retirement age in order to increase total working hours in the economy [5]. When societies postpone the retirement age, the individual older worker and the work place had to handle the situation caused by the increasing number of elderly people in society.

Most of the initiatives to retain people in work instead of early retirement are nowadays different economic incentives at the macro level, i.e. on the society level as a top down perspective to attract or force older worker at the micro level, i.e. on the individual level, to work longer [6] [7] [8] [9]. Although, some earlier studies stated economic incentives only to be one of the factors that influence older workers retirement decision [10] [11] [12] [13]. Whether older workers can and want to go on in an extended working life also depends on their health, physical work environment, mental/psychosocial work environment, working time and work place, knowledge and competence, work motivation and work satisfaction, the attitude from managers and the organisation/enterprise to older workers, the family situation and leisure activities [12]. To design a sustainable extend working life is complex and includes different areas and levels in the society. The organisation and enterprise managers regulate the possibilities for older workers to work longer, and the focus could not only be on the elderly. It is at the organisational and enterprise level that the decisions are to be taken to create a sustainable work place with possibility to an extended working life. To promote an active and healthy ageing at work and to create retirement age initiatives therefore also needs to include measures by managers in organisations and enterprises. Therefore it is important to in deep investigate the relation of how older worker experience their situation and how their managers' attitudes are to them as older employees. However, the older worker had to see work as a possible alternative at their individual position in society. The older workers decision on if they can and want to go on and work in an extended working life age or not occurs by four considerations: 1) their health and wellbeing in relation to: 
their physical and mental work environment, working time, work load and possibility to recovery; 2) personal economic; 3 ) if their possibility to social inclusion in a group is best inside or outside working life; 4) if their possibility to selfcrediting and motivation occupations is best inside or outside working life [10].

Objectives. The overall aim of this study was to examine the older employees' and their managers' attitude of active and healthy ageing at work. The specific attention was to investigate older employees own experience of their work situation; how older workers view their ageing in working life in relation to retirement. The aim was also to investigate their managers' attitude to older employees and their possibility to healthy ageing in work.

\section{Materials and Methods}

Health and social care is one of the largest employment sectors in Sweden and in many other countries. This sector is interested to study both regarding that is one of the largest sector and because the middle age are high in this sector. The data collection method chosen for this study was focus group interviews. These are group interviews in which everyone expresses opinions on a topic and the interaction in the group generates a process which provides another dimension to the interview [14]. The role of the researcher is to create shared knowledge in the group together with the informants. Focus group interviews can initiate and maintain a process that leads to conversations and discussions on the topic outside the interview situation.

In the study, older employees were defined as those aged 55 years and older. The study group consist of 18 informants (12 women and six men). In Sweden most of those who work in health and medical care are women and the study population was mirrored the unequal gender distribution with more women than men.

The focus groups with older workers consisted of 12 informants aged 55 - 63 years (mean 59 years) and working in health and medical care. Nine of the informants were women and three were men. The informants were separated into two groups of six individuals with a similar balance regarding gender and age. The same informants participated in both sessions in each group. The sample was voluntarily collected. However, the healthcare manager asked for volunteers who were interested in being part of the study and classified those who applied based on their work schedule. The focus group interviews were held in a small conference room near the informants' workplace and during their working hours, with two sessions per group. The informants sat in a circle with the researchers, with no table in between. Each interview session took two and a half to three hours. The study design with a follow up focus interview session allowed the informants to consider the interview questions between the two sessions and provide a richer data. The total transcribed interview time with older employees was approximately twelve hours. The interviews were semi-structured and the researchers asked the informants to: describe what it was like being older at work; the attitude to them as older workers in their workplace; how they re- 
garded their professional knowledge; their views on retirement and their retirement planning.

The manager group consist of first line manager, three women and three men, 40 - 63 years of age (mean 54 years). The manager sample was selected in the same way as the employees and from the same health care division. The semi-structured interview took two and a half hour. The discussed question were: the managers' attitude to their own older workers in the organisation and too older workers in general

\section{Results of Empirical Findings from the Focus Group Interviews}

The empirical results from the focus group interviews are presented below. The material is organised under two headline themes: Older employees and Managers out from the two informant groups. Those also include five under themes: ageing at work; older in the work organisation; active and healthy ageing in work in relation to retirement; the managers' attitude to older employees; and the mangers' possibility to healthy ageing in work.

\subsection{Older Employees}

\subsubsection{Ageing at Work}

When the interview session starts the informants were asked to write their name and age on a card and place it in front of their feet. However, some of the informants protested and stated that age was not important and that our society was overly fixated with age. Others wrote their age on the card without comment. However, many informants stared to talk during this activity and described themselves as not very old. One informant said: " $P m$ not a bit older. I think everyone else has got older but I haven' t." (Female aged 55 years). Another stated:

"Now my oldest child is 36 years, I can't be 30 anymore. That's true. But I don't think I have the attitude that I am old." (Female aged 63 years).

The informant described that their physical health were not as good as it were in younger days. Some describe their work as a problem to an active and healthy ageing. To handled their health to be as good as possible they had eliminated some of their leisure activities so they could rest and be fit for their next work shift. One said: "You can hardly cope with any spare time when you are working full-time here. It takes so much both physically and mentally. I cannot bear it. I.../ It has come with age. I get aches and pain throughout the body. I.../ All the demands have taken their toll. Many of us are ruined from the neck and down." (Female aged 58 years).

Beside that some reported at the same time that they no longer had the same strength and could not handle the stress in work as well as before. One mentioned: "You' re not as fast anymore. You' re more afraid of forgetting something, so you check it twice. Then it all takes even longer." (Male aged 61 years). It seems to be common in the informant group not to stand stress as well as in younger days, and another informant stated: "I can stand less stress nowadays." 
(Male aged 56 years). To handle their work situation some had eliminated some work activities because they felt they could no longer do as much. One informant described:

"I feel I cannot manage as much anymore. Everything takes a longer time and you cannot be activated as much. It sometimes feels like I don't bother going to a meeting. I ve actually had enough now. I would never have done that before." (Female aged 59 years).

Some describe them to have the right to take it easier now when they had become older. They describe the right to take it easier both in their careers and in free time. One said: "There are no longer any must-haves. I listen to what feels good to me, what I feel good about. I think that's nice. I am perhaps selfish, but today I make sure to feel good. Do it my own way. Previously when I had children living at home and a family to take care of, I always looked at the clock and ran to keep time. Today I never have a watch on me privately. It is nice. Tidying up, what's that?" (Female aged 57 years). Another stated: "I allow myself to just lie down and read a book. I do not clean up all the time at home, it is not what life is about. I rest. I allow myself this. I would never have done that before." (Female aged 58 years).

Ageing seems also to develop some of the informants' personality to be a more self-enough. One informant felt that she had grown professionally with age and had greater authority in her chosen profession. However, she also found it more difficult to listen to others ever since this developed age authority: "I think age plays a more important role than we dare admit to ourselves and others. You become a little bit more rigid with age. You become a little more yourself. You get more authority, and have a bit more difficulty when a person wants to impose on you." (Female aged 57 years).

To summary, the informants in this study had both positive and negative experiences of growing to older employees. The negative was that their health problem seems to be worse with increased age. However, the positive was that they nowadays trusted themselves better and not care as much about that other think of them.

\subsubsection{Older in the Work Organisation}

Age categorisation can easily lead to a person being perceived in a particular way because of their chronological age. Some informants stated that it could be difficult to speak up if they saw something wrong because they did not want to be perceived as a complaining or bullying old person. Those informants describe it negative for their wellbeing to be reduced as an old fool and categorised as bulling due to their age. One informant said: "When you are older and have greater knowledge you know how to do it. That is for better or for worse. To take an example: what the right treatment is or how patient journals should be written. It is difficult sometimes to point out things that are not good enough. I think that colleagues could easily perceive me as whiny because of my age and not listen to my experience and knowledge". (Male aged 61 years).

The informants described themselves to have better self-confidence and have 
found their roll in life through the experience knowledge life had learned them. One said: "It is positive that as an older worker you are more comfortable in your role. You have found your role over the years." (Male aged 61 years). The informants stated that they were more comfortable in their profession as older workers than they had been as younger workers. One older worker describe: "There is quite a lot positive about being older. That uncertainty as a new graduate is past. But one can never claim to be fully skilled and able to do everything, which can never be. But I still think it feels better now than then." (Female aged 61 years).

Some older employees pointed out that reorganisations were carried out over and over again without any particular improvements except that each new organisation model had a new name. However, many of the informants were tired of these reorganisations and did not want to experience another but want everything to remain the same as before.

Experience from a long working life meant that the informants felt they had a body of knowledge, which made them confident in their profession and their work tasks. One said: "Your knowledge mass increases with your experience obtained in the job over the years. Nowadays I know exactly what happens in the lines. It can be extremely saving in terms of suffering and administration to do it right from the start. That is the meaning of quality development. But to do this, one must have a great quantity of knowledge and that takes a number of years to obtain." (Female aged 57 years). Learning new things in old age sometimes describes as more difficult. How was the older workers experience of that? Someone of the informants reported experiencing more difficulty in learning new things nowadays: "You cannot teach an old dog to sit. When a young nurse teaches me something, so... I cannot understand. I do not know if it is more difficult to accept new ideas? That we think we can this? /.../ I have also noticed that with my older colleagues. That it is very difficult to get them to reconsider. To even get them to listen to what younger people say. It is much easier to teach a 40-year-old than a 60-year-old. That is frankly for sure." (Female aged 57 years). The older employees stated that aging and a long life increased the life experience and knowledge important in their work with patients. One said: "We elderly have life experience. It is clear that the life experience you get with the lived years is tremendous." (Female aged 63 years).

To summary, the informant's stated that it was positive growing old at work because the increased the knowledge of different experience from a long life was an access when carry out the tasks. However, growing old at work was negative regarding that the younger work mates and managers' sometime neglect the older employees experience knowledge, and that was very frustrating. Sometimes this neglecting even seem to be bulling and age discrimination.

\subsubsection{Active and Healthy Ageing at Work in Relation to Retirement}

Increasing age means that employees near the statutory retirement age and have the opportunity to leave working life earlier or later. Some informants were 
afraid that their work should decrease their possibility to healthy ageing. Therefore they cited health and a healthy ageing as one reason to withdraw from the labour market early to keep a good health in an upper age. One said: "I do not know if I have the energy to work until 65. If so I will need a walking aid to answer signals from the patients. I have back pain from time to time. Maybe I have a lot more pain than the patients. How will this be done? I think that 65 feel really impossible for me to work until. It gets worse year by year. We always have heavy patients and we are not getting better." (Female aged 59 years).

Some older employees seemed to be bitter about how work had worn out their bodies and how they were treated by the organisation. One said: "I think it feels wrong to have to voluntarily reduce your working hours when you feel you cannot cope with the work because of work related disability or diseases. I think when you have done a long working life in the organisation and are at the end of your working life, why should I have to declare myself sick or volunteer to work only 75 per cent. I think this feels completely wrong and that it is payback time for the organisation not for me." (Female aged 59 years). It was not only to get a disease or disabilities from work that make them consider leaving working life early to increase the possibility to an active and healthy aging in retirement. Also the intention to get some year as an active pensioner with meaningful leisure occupations makes some consider leaving working life early before they got a disability or disease. One said: "I cannot imagine working one hundred per cent up to 65. Ideally, one might start to slow down at 60, 61, shift down. I have seen so many tragic cases where individuals have laboured, and then they've got their disease just in time for retirement. I guess I will not postpone retirement too long. Before you know it you become sick yourself. I do not go around being afraid of illness or death, but if you make a realistic assessment the likelihood of a serious illness increases every year. It would be a shame to miss some good years when you are still young enough to travel and do things. The good years you like to make something of. The bad luck of getting a serious illness that influences me in my retirement choice." (Male aged 56 years).

The personal economic situation was described as associated with an active and healthy ageing. Some of the informants described they had to remain in work because of their private economic situation. One older woman noted that early retirement was not an option for her, despite her declining health. She has a very low pension after having been a housewife for many years while her children were growing up. She was now divorced and the children's father would not support her economically. However, there were also those who absolutely could not imagine continuing in their present work until they were 65 years, even if early retirement resulted in a financial penalty. One said: "I am single with everything financially resting on myself, so that can be a problem. But to 65. Never in my life!" (Female aged 57 years). Other informants were very happy at work and enjoyed the social inclusion that came with working life. Those describe work as a promoter to stay young. One describe: "I would probably work until 65, and then I want to come back and work certain holidays. /.../ I feel so 
insanely good in my work situation. I give a lot and get a lot. /.../ I have a feeling that I want to extend my life by part-time work a little after 65, but maybe it $s$ because you do not want to grow old. Then maybe I will retain my youth a little longer by that. I am very excited about ageing." (Female aged 57 years).

Some of the informants also described that work could promote a mentally healthy ageing. Those informants therefore plan to work in an extended working life. One said: "I will maybe decrease my hours a little in advance of 65 and then continue to work after 65. I have my old professor. He is 85 years old and still participates in meetings and he's really sharp in the head." (Male aged 57 years). Many other informants were also very stimulated by their work activities and reluctant to give them up totally. Some said: "I want to work. I do not think I want to quit and stay at home. Then you have to have another activity and I do not think I would find any as interesting. Well I am one who works a lot and I enjoy it. /.../ I find it rather difficult to imagine that, 65 then it is over." (Female aged 63 years).

To have a meaningful activity was described as important to stay healthy in old age. One described that if he had to stop working he does not know what to do as mentally stimulating as his previous work. He said: "I would probably be able to activate myself, but I can never imagine a life where I am not occupied." (Male aged 56 years).

The motivation to an independent life and be a part of the social interaction in working life resulted in some feeling unsure when they would leave work for retirement. It was not easy to weigh up things and make a decision if their active and healthy ageing will be best or worst if they extend working life. Some described it: "I am not sure if I want to extend my working life or not, I am a little unsure about it. But I would not dream of working full-time after seventy, but some want to." (Male aged 61 years). Another one said: "There are those who say they are not going to work one day after 60, but they work to 65 and more. You may not want to let go when you get there. I think the younger you are, the easier it is to say so. While the closer to retirement you get when you see what it really means, you say: "Well I can probably be here another month" and "I can probably take some more years." (Female aged 55 years).

To summary, to leave working life ant retire is a big step in life. The possibility as a pensioner to power and control over the own time and do whatever you want was appealing. However, people need motivating things to do and to be included in a social unit. If the work task was interesting the older employees seems to want to go on and work. Also to be included as one employed in an organisation with colleagues and tasks give a value to life. That inclusion in a social unit was difficult to leave and it seems like most of the informants were anxious to take the decision on when the time was ready to take the next step in the life course and become pensioners.

\subsection{The Managers}

\subsubsection{The Managers' Attitude to Older Employees}

There was also a negative dimension in the managers' description of their older 
workers and some stated older workers as brake pads who were afraid of organisational development. One manager stated: "Older workers are often a hindrance who always say. We have tried this, the old way is better." (Manger aged 55 years). On the other hand, the managers also stated that some older workers were very interested in change, development and reorganisations. Some managers commented that it was very good to have those older employees who had long working experience and could suggest how to develop, improve and change the current organisation. One said: "Progressive older employees are great to have. They want to make it new, while they have history with them about what happens when you try different things. They do not make the same mistake again, but stop and suggest another way instead." (Manager aged 42 years). Many managers stated active and healthy older workers as very positive. The described older workers experience knowledge as a treasure for the health and medical care organisation. One manager said: "Older workers have a tremendous life experience. They have built up a wealth of knowledge and life experience after working with seriously ill people. When you have worked for 30 years in the profession you can do it, you know how the patients feels and the side-effects. It feels good to have this expertise in the department." (Manager aged 45 years).

To summary, the mangers' seem to have an ambivalent thinking of the older employees' value to the organization. They seem to value their experience knowledge if that go in the same direction as the planning for organizational development. However, if the older employees experience was that the plans were waste of time and resources the managers' attitude was that the older employees were a hindrance for the development.

\subsubsection{The Managers' Attitude to Older Employees' Possibility to Healthy Ageing in Work}

The managers mostly describe older workers health out from the view of the organisational use of older workers. They describe that older worker more often was tired and not as attractive to new recruit. The managers do not notes older workers possibility to healthy ageing at work. Instead some describe that older workers got decreased sensory organs and health problem that could affect their work. As one manager put it: "The knee, back and sight is not the same then you are 60. I myself do not want to get treated or needled in my arm by a nurse who is older and not see my veins as good anymore." (Manager aged 54 years).

To summary, the managers generally seem to classified older employees as a group of people with ageing bodies and minds. Due to that they did not see them as productive and not anyone to trust and be sure of anymore. The managers' attitude seems to be that it was not the organisations responsibility to take care of the older employees' health problems that make it problematic to go on with some tasks. If older employees could not fulfil the duty anymore he or she has to leave their employment and the managers need to replace them with other employees. 


\section{Discussion}

The current demographic situation in many industrial countries has resulted in governments suggesting postponing the retirement age for all occupations. This study therefore examined how older employees' perceived their work situation in relation to how their managers perceived their older employees. According to the findings in the focus group interviews, experiences vary between individuals and managers in the same work organisation. A practical social significance was that the older employees and the managers seem to have different view regarding factors of importance to an extended working life. However, neither the older employees nor their managers seem to be very fond of the society's intention to extend the working life and delay the retirement age.

This study's' utilised issues of importance for older employees' and managers' attitude to each other and to an extended working life is described and discussed below.

\subsection{Ageing in Working Life}

The managers stated that they preferred younger individuals when they would recruit due to the decreased physical and mental health and because the older ones not will stay for as long time. On the other hand, older workers mostly have the best experienced knowledge which was good to have in the organisation. In the context of postponing retirement age in many western countries these results indicate that it is important to view each employee as an individual rather than to generalise based on chronological age [6] [11] [15] [16] [17] [18]. Chronological age depends on time going by. Though there are also other types of age definitions that had to be considered in relation to an extended working life. Biological ageing depends on genetic heritage, people's lifestyles, injuries and diseases during their (working) life. Mental ageing is a definition out of individual development and cognitional aspects. Social ageing define social inclusion and identity compared with social situations through the live course. However, functional age definition includes the interplay between biological, mental, social and chronological age. Although how long people have lived affects them in common, functional ageing can differ greatly between people in the same chronological stated age. Ageing and to become an older worker is therefore an effect of social circumstances, life style, injuries, diseases and genetic heritage, which together create what we describe as ageing. Functional age is due to that more important than chronological age in working life and to extend working life or retire, according to the informants in this study. It might therefore not be a general "best before" date on employees only based on chronological age as the only criteria for statutory retirement age.

\subsection{Older at Work}

Peoples are categorised different in a social context corresponding to their age and growth throughout their life course. Age seemed to be a sensitive question for some of the informants, probably because it categorises people and makes 
some of the informants (aged 55 years and older) feel that they no longer belong to the elite age group. There are different definitions of ageing, but age elitism tends to be based on chronological age and occurs in both work and leisure, with productivity and activity being primarily associated with the middle-aged [6] [16] [17] [18]. Based on this categorisation and the associated age elitism, changes in children, adolescents and young people are described as on-going development, while changes after middle age are referred to as ageing. The informants were annoyed that age elitism is mostly associated with chronological age and bodily degeneration and overlooks the mental and social development acquired through life experience and wisdom. Such categorisations can easily contribute to stereotypical images of a certain age group [19] [20] [21] [22].

Some informants associated ageing and retirement with a stereotypical attitude of weakness and negative physical and mental ability, but did not include themselves in that image. However, the experience of ageing and being an older employee varied widely between individuals. According to the informants, stressful or physically demanding work had a significant impact on their experience of ageing in relation to work. Others reported that ageing had increased their self-confidence and authority in the work situation, and also seemed to empower them to prioritise between work and leisure. Age in itself has been reported to be an instrument to be taken into account in management decisions regarding time schedule, work routine and organisation to increase the productivity [6] [21] [22]. However, the results in this study suggest that such decisions should be based on their functions and not chronological age.

\subsection{Work Organisation}

Informants seemed to experience conflict between the generations. This seemed to be negative and create uncertainty about how to behave towards each other in the workplace. The professional role does not occur in isolation, but involves an individual and his/her expectations of the work, attitudes and values [6] [23] [24]. The informants reported experiencing some stereotypical attitudes and some indicated that they were afraid to be seen as complaining and thus avoiding pointing things out they perceived to be wrong. It was clear that the older workers in this study felt that acting in a particular way could be difficult because it could be attributed to ageing and therefore rejected, even if it concerned the best way to handle a patient based on long experience of the work. Interdependency in the working group can create anxiety about being excluded from that 'community' [25] [26]. When the working situation feels unsafe and new changes are underway, stereotypical attitudes and creation of scapegoats tend to be particularly evident. Stereotypical attitudes in the workplace owing to age could therefore be a security risk and negative for production if fear of being excluded in the work group causes employees to avoid whistle blowing when something is wrong.

Negative age stereotyping can affect not only older worker, but could occur between different age groups [2] [21] [22]. For example, many informants de- 
scribed their younger work mates in a stereotypical way, as messy and not cleaning up after themselves. People are social creatures and most want to be part of a social context. Dissatisfaction with the work situation, reorganisations, stress and a stressful work environment all contribute to unhappiness with work and a tendency to leave work [10] [25] [26]. Social communities such as groups of employees and social control in these groups are important factors for employees' job satisfaction and psychosocial health.

The older workers in this study also were less interested to remain in work if the attitude to older workers was negative among managers and co-workers. Earlier studies have stated that attitude to older people in the workplace is a determining factor for whether older workers extend their working life [11] [17] [27]. To manage the older worker's situation organisations need to be flexible to test different methods as reducing working hours, reducing work load and demands, increasing economic incentives, increased esteem and possibilities for learning despite old age, re-deployment to less demanding parts of the organisation. Motivational activities and positive expectations from managers and employers are also reported to be very important [11] [27]. Although, those arrangements are sometime not possible to manage in reality and in relation to organisations productivity goal, budgets and demands on productivity give the strongest restrictions to introduce age-adjusted leadership [7]. Attitude is also important in management and a strong guiding principal in (work) organisation. Age adjusted management is therefore stated not as important to managers who plan early retirement themselves [28]. Nevertheless, some age-adjusted management programmes which reduce work pace and working time stated increased average retirement age, good work environment experience, good productivity and good economic profits for the company [29]. The result from this study indicated that older workers were less interested to remain in work if the attitude to them was negative and ignoring. Skilled individuals therefore consider leaving working life too soon, which is negative both for the organisations and for the society production outcome.

\subsection{Professional Knowledge}

The informants described it as positive to have great experience-based knowledge after a long (working) life, which gave them a solid foundation to stand on in their professional role by their mentally ageing. They reported that the opportunity to share knowledge increased social interaction and the motivation to work. This has also been noted in previous studies [10] [30] [31].

Knowledge has been described as a power factor, causing differences in status [32] [33]. Some older informants seemed to experience difficulty in learning new things. However, according to earlier research older individuals in general do not have cognitive problems in learning new things, but learn in a different way than younger people [34] [35]. Older worker have also more easy to learn if training be adapted accordingly throughout (working) life. The experiencebased knowledge that an individual has accumulated over a long working life is 
important capital for the organisation that should be utilised. This is certainly important in some occupations, e.g. nurses' knowledge built up by practice cannot only be transmitted through theoretical training, but with practical transmission [34] [35]. However, not all the informants seemed to have been given the same opportunity to pass on knowledge. It can be concluded that older workers with lower status in the organisation possibly do not have the same opportunities as those with higher status, resulting in them feeling less valued and interesting to the organisation and deciding not to extend working life. This challenges the intention of governments to motivate people to an extended working life and raise the retirement age for all occupations. It seems therefore important to offer employees the possibility to new knowledge regardless of their age and hierarchal position in the organisation.

\subsection{Retirement}

Good health is one of the most important factors for inclusion in working life [6] [12] [15] [36] [37]. Health decrease with biological ageing as people get older, but the variation is huge [38] [39]. Some informants described it as impossible to work until 65 years because of their health. However, the informants work with very sick patients and also some of those without any health problems feel that it is important to leave working life before they get a disease. Early retirement was seen as a way to avoid becoming worn out prematurely. This attitude to withdrawal from working life to avoid becoming worn out is also reported in an earlier study [11] [40]. Due to this attitude health, and not age, could be a reason to early retirement both to informants how suffer health problems as well as to those how not have any health problem.

The risk of lower income after retirement seemed to be a problem for some female informants. This can be a reason to stay in work [41] [42]. However, some who described their work as hard did not want to extend their working life, despite financial problems. Earlier studies show that salary itself does not motivate people to work if their work is hard [43] [44].

Some of the older respondents could not imagine a life without the social inclusion of the workplace and stimulating work tasks. Higher inclusion and higher status in the social group generally increase people's commitment to continue participating in working life [30] [42] [45] [46]. Some of the informants also reported that they not have any activity as interesting as their work and therefore they do not know when they will be ready to retire. Earlier studies have found that workplaces where employees experience empowerment, appreciation and the possibility for meaningful activities lead to well-being and are healthy [46].

The informants in the present study seemed to weigh retirement against how they experienced their work situation in relation to leisure. In discussions on retirement, the informants pointed out that they consider: their health in relation to work; economic incentives to extend working life or ability to live on the pension provided; whether social inclusion is better inside or outside working life; and whether possibilities for self-crediting and meaningful activities are better 
inside or outside working life.

\subsection{Study Limitations}

The informant population in this study is small and additional the result from a qualitative study is not able to be generalized to a greater population. However, the findings agrees with factors determined in earlier studies on older workers retirement decisions [6] [10] [11] [12] [15] and on a theoretical model (the swAge model, www.swAge.org) regarding factors of importance for a sustainable work life participation. The quotation from the interviews gives a deeper understanding for the older employees' situation and of the managers' attitude to their older employees.

\section{Conclusions}

Many countries need to motivate more people to work to a greater age in the future due to demographic changes. In the context of postponing retirement age, a practical social significance is that the older workers in this study considerate retirement or extend working life based on their health in relation to their work situation, their personal economic, their social inclusion at work and their possibilities for self-crediting activities, rather than their chronological age as a best before date to end up work. It is important that managers and organisations take account of older workers' views on changes in the workplace in order not only to reduce uncertainty, stress and dissatisfaction, but also to utilise their experience and knowledge in prioritisation and work planning. The focus needs to be on each employee's needs and ability to perform their tasks and how to make the productivity, not on their age. Therefore age-adapted management based on health and ability, could be a way to increase the retirement age and make a more sustainable working live to all ages. This may postpone retirement age by change attitude from focus on chronological age to focus on personal functional possibilities and needs. However, the older employees in this study experienced negative stereotyping due to their age and they do not receive the right opportunity and occasion at the workplace to be productive anymore. Those negative attitudes seem to force their willing to withdrawal from working life. Those feelings were stated by that the managers in this study seem not to regard their older workers as productivity as the younger employees and not easy to control and direct. The managers were actually not as interested to keep their older worker if they have younger employees with equal education to relay on. If the society wants more people to go on and work to an older age, the managers' attitude to older employees needs to be changed by different incentives. In the intention to create a more sustainable working life for all ages, more interventions studies and research are needed regarding incentives and regulations for increased age-adapted health and ability management.

\section{References}

[1] OECD (2016) Health at a Glance Europe. The Organisation for Economic Co-Op- 
eration and Development.

[2] World Economic Forum (2012) Global Population Ageing Global Agenda Council on Ageing Society Geneva.

[3] OECD (2007) Population Pyramids in 2000 and 2050. The Organisation for Economic Co-Operation and Development Statistics Portal: Demography and Population. http://www.oecd.org/dataoecd/52/31/38123085.xls

[4] OECD (2011) Social Indicator. Old Age Support Rate. The Organisation for Economic Co-Operation and Development.

http://www.oecd-ilibrary.org/social-issues-migration-health/society-at-a-glance-201 1/old-age-support-rate_soc_glance-2011-10-en

[5] Eurostat. (2010) Work Session on Demographic Projections. Luxembourg, Publications Office of the European Union.

http://ec.europa.eu/eurostat/documents/3888793/5848129/KS-RA-10-009-EN.PDF/ fbaff784-8e78-417b-8b51-7f8fdf2f3031

[6] Nilsson, K. (2016) Conceptualisation of Ageing in Relation to Factors of Importance for Extending Working Life: A Review. Scandinavian Journal of Public Health, 44, 490-505. https://doi.org/10.1177/1403494816636265

[7] Furunes, T. and Mykletun, R. (2011) Managers' Decision Latitude for Age Management: Do Managers and Employees Have the Same (Implicit) Understanding? In: Ennals, R. and Salomon, R.H., Eds., Older Workers in a Sustainable Society, Labor, Education \& Society, Peter Lang Verlag, Frankfurt, 107-116.

[8] Midtsundstad, T. (2011) Inclusive Workplaces and Older Workers. An Analysis of Companies' Investment in Retaining Senior Workers. International Journal of Human Resource Management, 22, 1277-1293.

https://doi.org/10.1080/09585192.2011.559099

[9] Salomon, R.H. and Hilsen, A.I. (2011) A Three Phase Perspective on Senior Polices. In: Ennals, R. and Salomon, R.H., Eds., Older Workers in a Sustainable Society, Labor, Education \& Society, Peter Lang Verlag, Frankfurt, 81-92.

[10] Nilsson, K. (2011) Attitudes of Managers and Older Employees to Each Other and the Effects on the Decision to Extended Working Life. In: Ennals, R. and Salomon, R.H., Eds., Older Workers in a Sustainable Society, Labor, Education \& Society, Peter Lang Verlag, Frankfurt, 146-157.

[11] Nilsson, K. (2012) Why Work beyond 65? Discourse on the Decision to Continue Working or Retire Early. Nordic Journal of Working Life Studies, 2, 7-28. https://doi.org/10.19154/njwls.v2i3.2361

[12] Nilsson, K., Rignell, H.A. and Rylander, L. (2011) Factors Influencing the Decision to Extend Working Life or to Retire. Scandinavian Journal of Work Environment \& Health, 37, 473-480. https://doi.org/10.5271/sjweh.3181

[13] Wind, G.G.A., Ybema, J.F., Blatter, B.M., Burdorf, A., Bongers, P.M. and Van, B.A.J. (2014) Health, Job Characteristics, Skills, and Social and Financial Factors in Relation to Early Retirement-Results from a Longitudinal Study in the Netherlands. Scandinavian Journal of Work Environment \& Health, 40, 182-194. https://doi.org/10.5271/sjweh.3393

[14] Krueger, R.A. and Casey, M.A. (2009) A Practical Guide for Applied Research. Sage Publications, London.

[15] Nilsson, K., Rignell-Hydbom, A. and Rylander, L. (2016) How Is Self-Rated Health and Diagnosed Disease Associate with Early or Deferred Retirement: A Cross Sectional Study with Employees Aged 55-64. BMC Public Health, 16, 886.

https://doi.org/10.1186/s12889-016-3438-6 
[16] Odén, B. (2012) Äldre Genom Tiderna. [Older People through the Centuries.] Carlssons Bokförlag, Stockholm.

[17] Taylor, P. (2011) Is Early Retirement History? In: Ennals, R. and Salomon, R.H., Eds., Older Workers in a Sustainable Society, Peter Lang Verlag, Frankfurt, 225232.

[18] Tornstam, L. (2011) Aldrandets Socialpsykologi. [Social Psychology of Ageing.] Nordstedts Förlag, Stockholm.

[19] Glover, I. and Branine, M. (2001) Ageism in Work and Employment. Ashgate Publishing, Farnham.

[20] McGoldrick, A.E. and Arrowsmith, J. (2001) Discrimination by Age: The Organizatonal Response. In: Glover, I. and Branine, M., Eds., Ageism in Work and Employment, Ashgate Publishing, Farnham.

[21] Kathleen, R. (2007) Othering Older Worker Identity in Recruitment. Human Relations, 60, 1701-1726. https://doi.org/10.1177/0018726707084305

[22] Standifer, R.L., Lester, S.W., Schultz, N.J. and Windsor, J.M. (2013) How Age Similarity Preference, Uncertainty, and Workplace Challenges Affect Conflict. Human Relations, 66, 1597-1618. https://doi.org/10.1177/0018726713482012

[23] Nilsson, K., Östergren, P.O., Kadefors, R. and Albin, M. (2016) Has the Participation of Older Employees in the Workforce Increased? Study of the Total Swedish Population Regarding Exit Working Life. Scandinavian Journal of Public Health, 44, 506-516. https://doi.org/10.1177/1403494816637262

[24] Thorsen, S., Rugulie, R., Løngaard, K., Borg, V., Thielen, K. and Bjorner, J.B. (2012) The Association between Psychosocial Work Environment, Attitudes towards Older Workers (Ageism) and Planned Retirement. International Archives of Occupational and Environmental Health, 85, 437-445. https://doi.org/10.1007/s00420-011-0689-5

[25] Jokela, M., Ferrie, J.E., Gimeno, D., Chandola, T., Shipley, M.J., Head, J., Vahtera, J., Westerlund, H., Marmot, M.G. and Kivimäki, M. (2010) From Midlife to Early Old Age. Health Trajectories Associated with Retirement. Epidemiology, 21, 284-290. https://doi.org/10.1097/EDE.0b013e3181d61f53

[26] Vaillant, G.E., Di, R.A.C. and Mukamal, K. (2006) Natural History of Male Psychological Health, XV: Retirement Satisfaction. American Journal of Psychiatry, 163, 682-688. https://doi.org/10.1176/ajp.2006.163.4.682

[27] Stattin, M. (2005) Retirement on Grounds of Ill Health. Occupational \& Environmental Medicine, 62, 135-140. https://doi.org/10.1136/oem.2004.015669

[28] Mykletun, R. and Furunes, T. (2011) The Ageing Workforce Management Programme in Vattenfall AB Nordic, Sweden. In: Ennals, R. and Salomon, R.H., Eds., Older Workers in a Sustainable Society, Peter Lang Verlag, Frankfurt, 93-106.

[29] Mykletun, R., Furunes, T. and Solem, P.E. (2012) Managers' Beliefs about Measures to Retain Senior Workforce. Nordic Journal of Working Life Studies, 2, 109-127. https://doi.org/10.19154/njwls.v2i3.2366

[30] Forma, P., Tuominen, E. and Väänänen-Tomppo, I. (2005) Who Wants to Continue at Work? Finnish Pension Reform and the Future Plans of Older Workers. European Journal of Social Security, 7, 227-250. https://doi.org/10.1177/138826270500700303

[31] Saurama, L. (2004) Experience of Early Exit. A Comparative Study of the Reasons for and Consequences of Early Retirement in Finland and Denmark in 1999-2000. Finnish Centre for Pension Studies, Helsinki.

[32] Cheung, F. and Wu, A.M.S. (2009) An Investigation of Predictors of Successful Aging in the Workplace among Hong Kong Chinese Older Workers. International 
Psychogeriatrics, 24, 449-464. https://doi.org/10.1017/S104161021100192X

[33] Doyle, Y.G., McKee, M. and Sherriff, M. (2012) A Model of Successful Ageing in British Populations. European Journal of Public Health, 22, 77-86. https://doi.org/10.1093/eurpub/ckq132

[34] Mather, M. (2010) Aging and Cognition. Cognitive Science, 1, 346-362. https://doi.org/10.1002/wcs.64

[35] Salthouse, T. (2000) Aging and Measures of Processing Speed. Biological Psychology, 54, 35-54. https://doi.org/10.1016/S0301-0511(00)00052-1

[36] Gueorguieva, R., Sindelar, J.L., Falba, T.A., Fletcher, J.M., Keenan, P., Wu, R. and Gallo, W.T. (2009) The Impact of Occupation on Self-Rated Health: Cross-Sectional and Longitudinal Evidence from the Health and Retirement Survey. Journal of Gerontology: Social Sciences, 64B, 118-124. https://doi.org/10.1093/geronb/gbn006

[37] Nilsson, K. (2016) Interventions to Reduce Injuries among Older Workers in Agriculture: A Review of Evaluated Intervention Projects. WORK: A Journal of Prevention, Assessment, and Rehabilitation, 55, 471-480. https://doi.org/10.3233/WOR-162407

[38] Holliday, R. (2010) Ageing and the Decline in Health. Health, 2, 615-619. https://doi.org/10.4236/health.2010.26092

[39] Koolhaas, W., Van, K.J.J., Groothoff, J.W. and Brouwner, S. (2012) Towards a Sustainable Healthy Working Life: Association between Chronological Age, Functional Age and Work Outcomes. European Journal of Public Health, 22, 424-429. https://doi.org/10.1093/eurpub/ckr035

[40] Cobb-Clark, D.A. and Stillman, S. (2009) The Retirement Expectations of MiddleAged Australians. The Economic Record, 85, 146-163.

https://doi.org/10.1111/j.1475-4932.2009.00543.x

[41] Bidewell, J., Griffin, B. and Hesketh, B. (2016) Timing of Retirement: Including a Delay Discounting Perspective in Retirement Models. Journal of Vocational Behavior, 68, 368-387. https://doi.org/10.1016/j.jvb.2005.06.002

[42] Coppola, M. and Benita, W.C. (2010) How Sensitive Are Subjective Retirement Expectations to Increases in the Statutory Retirement Age? The German Case. Mannheim Research Institute for the Economics of Ageing, Mannheim, 207. http://www.mea.mpisoc.mpg.de/uploads/user_mea_discussionpapers/1103_207-10. pdf

[43] Hult, C. and Stattin, M. (2009) Age, Policy Changes and Work Orientation: Comparing Changes in Commitment to Paid Work in Four European Countries. Population Ageing, 2, 101-120. https://doi.org/10.1007/s12062-010-9023-3

[44] Wang, M. and Shultz, K.S. (2010) Employee Retirement: A Review and Recommendations for Future Investigation. Journal of Management, 36, 172-206. https://doi.org/10.1177/0149206309347957

[45] Park, J. (2010) Health Factors and Early Retirement among Older Workers. Statistics Canada, 75, 5-13.

[46] Siegrist, J., Wahrendorf, M., Von, K.O., Jürges, H. and Bösch-Supan, A. (2007) Quality of Work, Well-Being and Intended Early Retirement of Older EmployeesBaseline Results from the Share Study. European Journal of Public Health, 17, 62 68. https://doi.org/10.1093/eurpub/ckl084 
Submit or recommend next manuscript to SCIRP and we will provide best service for you:

Accepting pre-submission inquiries through Email, Facebook, LinkedIn, Twitter, etc. A wide selection of journals (inclusive of 9 subjects, more than 200 journals)

Providing 24-hour high-quality service

User-friendly online submission system

Fair and swift peer-review system

Efficient typesetting and proofreading procedure

Display of the result of downloads and visits, as well as the number of cited articles Maximum dissemination of your research work

Submit your manuscript at: http://papersubmission.scirp.org/

Or contact jss@scirp.org 